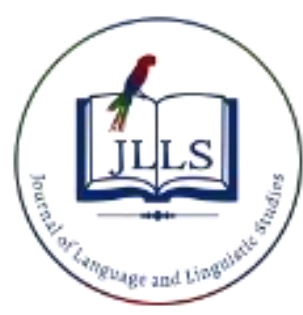

Available online at www.jlls.org

JOURNAL OF LANGUAGE AND LINGUISTIC STUDIES

ISSN: $1305-578 \mathrm{X}$

Journal of Language and Linguistic Studies, 16(2), 978-992; 2020

\title{
Readability of Turkish tales
}

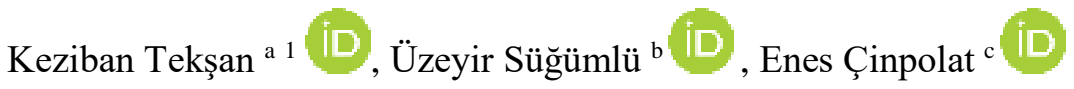 \\ ${ }^{a}$ Ordu University, Ordu, Turkey \\ ${ }_{\text {b Ordu University, Ordu, Turkey }}$ \\ APA Citation: \\ ${ }^{b}$ Tokat Gaziosmanpaşa University, Tokat, Turkey
}

Tekşan, K., Süğümlü, Ü., \& Çinpolat, E. (2020). Readability of Turkish tales. Journal of Language and Linguistic Studies, 16(2), 978-992.

Submission Date: 07/02/2020

Acceptance Date: 11/03/2020

\begin{abstract}
The present study aims to determine the readability and clarity levels of certain Turkish tales for middle-school students. The study was conducted with a survey model. The study material consists of three tales each chosen from the books titled Az Gittik Uz Gittik and Masal Masal İçinde, and the study group consists of 90 students who were studying in a middle school located in the central district of a province in the Spring semester of the 20182019 academic year. The data collection tools used in the study include the Ateşman Readability Formula, Çetinkaya-Uzun Readability Formula, and a Cloze Readability Application. Data collection was performed in two stages. In the first stage, the readability conditions of the first one hundred words of the tales were determined in order to apply the readability formulas. In the second stage, the Cloze Readability application was completed within three weeks by applying it to the study group using two texts per week. The analysis of the data was performed using the Descriptive Analysis technique. It was determined that the tales had a readability level of "easy" according to the Ateşman readability formula, and "educational" according to the Çetinkaya-Uzun readability formula. It was found that the book titled $A z$ Gittik $U z$ Gittik had a readability level of "difficult (frustration)" while the book titled Masal Masal İçinde had a readability level of "educational (assisted)" according to the Cloze Readability application.
\end{abstract}

(C) 2020 JLLS and the Authors - Published by JLLS.

Keywords: reading habit; Turkish tales; readability; cloze readability

\section{Introduction}

Today, people have to read and learn more in order to access and use the rapidly increasing and changing sources of information. This situation requires individuals to possess the habit of reading as individuals who acquire the habit of reading read all types of sources voluntarily and engage in constant repeated reading.

Reading improves society as well as the individual. One of the most important goals of mother tongue education is to raise individuals who possess reading skills and reading habits. Texts are the main sources of reading skills. Texts are significant in turning reading into a pleasure and habit and preventing

\footnotetext{
${ }^{1}$ Corresponding author. Tel.: +90452 2265200

E-mail address: kezibanteksan@ gmail.com
} 
boredom. In this context, the suitability of the texts to the level of the reader is discussed. The suitability of the texts to the reader is not adequate in terms of content. However, the sentence and word lengths in the texts should be appropriate for the level of the reader. That is because it was clearly demonstrated by previous studies that the linguistic features constituting the text affect the processing and interpretation of the texts by the reader positively or negatively (Çetinkaya, 2010, p. 2). The concept of readability has emerged as a result of the examination of the effects of the aforementioned linguistic features that constitute the text on comprehension.

Studies on readability, which is defined as "The easy or difficult comprehension of the text by the reader" (Ateşman, 1997, p. 71), date back to old times (Çetinkaya, 2010). In the studies conducted to determine the suitability of the texts to the reader level, variables such as word length, sentence length, and difficult words were used. It is widely accepted that a text consisting of short sentences and words is easily readable by an average reader. Accordingly, readability formulas are generally developed on the quantitative and calculable properties of the text, such as average word length and average sentence length. It is a known fact that an accomplished reader will be bored while reading texts consisting of simple words and sentences, and a lower-level reader will be bored with texts consisting of long words and sentences, which will cause both readers to stop reading the texts. Thus, readability studies are conducted to determine the difficulty of texts and their suitability to the level of the reader. Ulusoy (2009) states that readability is an important problem. It is a significant and difficult task for teachers to find a balance between the reading abilities of students and the difficulty levels of texts. That is because studies show that as people get older, their language development level and the length of the words and sentences they use increase accordingly (Karatay, Bolat \& Güngör, 2013, p. 607).

There are previous studies in the literature conducted with the aim of determining the readability of the texts in course books (Bağcı \& Ünal, 2013; Çiftçi, Çeçen \& Melanlığlu, 2007; Karatay, Bolat \& Güngör, 2013; Okur \& Ar1, 2013; Tosunoğlu \& Özlük, 2011; Zorbaz, 2007). The aim is to encourage students to read books other than course books, therefore enabling them to gain the habit of reading and to enjoy reading all kinds of books. Therefore, it is important to provide students with books that are suitable to their reading levels. In this context, readability should not be ignored in the selection of texts and books to be suggested to and read by students (Ceran, 2015, p. 27). There are also other studies on the determination of the readability level of the books that students read outside the classroom (Çeçen \& Aydemir, 2011; Çinpolat, 2019; Güneş, 2000; Temizyürek, 2010).

No studies were found examining the readability levels of tales read by students, except for the study conducted by Zorbaz (2007). However, "fairy tales should be separate for age groups and these tales should be selected pedagogically in accordance with age groups." (Akçaalan, 2015, p. 136). The significance of tales in encouraging children to learn and enjoy their mother tongue is widely accepted (Bilkan, 2009; Çetinkaya, 2007; Dilidüzgün, 2007; Güney, 1974; Karatay, 2007; Yavuz, 2002). Tales teach children how to use their mother tongue like a tool in the hands of a worker and demonstrate the various talents, agility, richness, and delicacy of a language (Boratav, 1958, p. 15). Tales are natural devices for mother tongue education in terms of reflecting the delicacy and richness of colloquial language with idioms, proverbs, etc. (Sever, 2003). Tansel (2009) emphasized the importance of tales in children's education by stating "I believe that the tendency to read, reading habits, and the delicacy of the mother tongue can be taught through tales.". Şirin (2000) stated that every individual, young and old, enjoy listening to tales and "There is no other genre that prepares people for life and nourishes their emotions as much as fairy tales."

Yalçın and Aytaş (2002) explain the relationship between tales and children's literature as "Turkish tales are important sources in the mental development of children. Especially with the works of our educators, our tales can partake in the world children's literature" (p. 49). 
One of the researchers who conducted studies on Turkish tales is Pertev Naili Boratav. He is a folklorist who compiled folktales and prevented them from vanishing. Boratav published twenty-two fairy tales and twenty-one rhymes in his book Zaman Zaman Içinde (1958), and forty-eight tales and nineteen Karatepeli stories in his book Az Gittik Uz Gittik (1969). At the end of the book, there is an article titled Türk Masalı Üzerine, which gives information on the importance of tales, their relationship with other genres and how authors make use of this genre. In the preface of Zaman Zaman Içinde, Boratav (2009) explains how he put down the tales he compiled on paper as follows:

"Folk tales have reached a maturity in style, language, and expression within the oral tradition. Thus, it is best to publish a tale written by the master storyteller without making any changes. I say this figuratively, of course. Although they did not alter the subject, individuals who have studied tales so far did not bother to abide by the style and acted with complete freedom to the point of rewriting the story from the beginning. I believe that the mark left by the artist on the wording and style of the tale should be reflected. While doing this, there will, of course, be some small touches that are necessary in putting oral narration to paper. These can be listed as eliminating the differences in accent, grammatical alterations that vary according to regions, and small problems that are only beneficial in verbal expression and harmful to the value of written expression... This type of intervention will not harm the structure of the tale and perhaps evaluate it within its own structure without spoiling it. I applied this methodology in the preparation of the tale texts in my book." (p. 12)

Ahmet Ümit, a contemporary writer, also wrote tales for children. The author has fairy tale books titled Masal Masal İçinde and Olmayan Ülke. Ahmet Ümit explains how he writes tales in his answer to the question: "You have two tale books. Are these tales fictional products of your imagination? Or, did you rather create these tales in accordance with the stories you have heard from your elders?" (Ilicak, 2014):

These were inspired by the tales my mother used to read to me. My mother is an excellent story-teller and she read lots of tales to me. These are what I remember, of course, I added, altered, and stylized some and made them more contemporary. However, I had heard the story of the main tale from my mother. My mother also heard it from someone else, she did not produce the story on her own. She contributed a lot to the stories she heard. However, these are anonymous tales and I rewrote these anonymous tales. They are anonymous in origin. Unfortunately, the tale tradition is dying. Therefore, I have produced this work with great pleasure for the survival of the tradition." (p. 700)

Boratav wrote the tales as true to the original as possible, while Ümit rewrote the tales he had heard from his mother. The writing dates of the tales differ as well. Boratav published his book Az Gittik $U z$ Gittik in 1969 and Ümit published his book Masal Masal Iç̧inde in 1995. The difference between the writing dates of the two tales and the rapid change in social life during the time period in between may affect the readability of the tales. Tales, which are products of oral literature, reflect the language characteristics of the region as well as the period and place where the tale was told.

\subsection{Research questions}

The aim of the present study is to determine the readability levels of six fairy tales in the tale books titled Az Gittik Uz Gittik and Masal Masal Içinde, and to reveal whether these fairy tales are comprehensible using the cloze readability application for middle-school students. Accordingly, answers for the following questions were sought:

1. What are the readability levels of the tale books according to the Ateşman readability formula?

2. What are the readability levels of the tale books according to the Çetinkaya-Uzun readability formula?

3. What is the comprehensibility level of the tale books for students with the cloze readability application? 
4. What is the comprehension condition of the students based on their gender?

5. What is the comprehension condition of the students based on their grades?

\section{Method}

\subsection{Study Design}

This study, which includes the readability conditions of certain tales according to various readability formulas and the cloze readability application performed by the students, was carried out with the quantitative survey model approach. The survey model aims to describe past or present situations (Karasar, 2012).

\subsection{Sample / Participants}

The study material of the research consists of three fairy tales randomly selected from the tale books Az Gittik Uz Gittik (Boratav, 2008) and Masal Masal İçinde (Ümit, 2017). These books were chosen in order to reveal the difference in readability that is thought to emerge due to the difference in writing periods and style. The book Az Gittik Uz Gittik was written in 1969 as a compilation of fairy tales that were published by remaining true to their original versions. The book titled Masal Masal İçinde was written in 1995 by the author based on fairy tales that he had heard in his childhood. The tales titled Dünya Güzeli (1), Tilki ile Çimenci Padişahının Oğlu (2), and Benli-Bahri (3) were selected from the book Az Gittik Uz Gittik and the tales titled Masal Masal Içinde (1), Şapkacı'nın Anlattıkları (2), and Köradam 'in Anlattıkları (3) were selected from the book Masal Masal İçinde.

The study was conducted in a middle school located in the central district of a province in the Black Sea Region of Turkey in the Spring semester of the 2018-2019 academic year with the aim of determining the cloze readability scores of the selected tales. The study group consisted of a total of 90 volunteering middle school students involving 73 females and 17 males. The participants consisted of 25 fifth-grade, 21 sixth-grade, 22 seventh-grade and 22 eighth-grade students. The age of the participants ranged between 10 to 14 . Convenience sampling, which is one of the deterministic sampling methods, was used in the determination of the study group (Creswell, 2013; Christensen, Johnson \& Turner, 2015; Robson, 2017). The necessary permissions were obtained from the Provincial Directorate of National Education for the cloze readability application.

\subsection{Data collection procedures}

The data collection phase of the study was carried out in two stages. In the first stage, the first hundred words of each of the six tales selected for the purpose of applying readability formulas were extracted for calculation, the necessary sentences, words, and syllables were determined in the texts, and the readability conditions were determined according to the readability formulas.

In the second stage, the cloze readability application was completed in three weeks by applying two texts per week to the study group. Before the application, the definition and implementation of the cloze readability application was explained to each class and a pilot application was performed with a tale outside the study materials. It was explained to the students that the text should be read in full, and that all spaces are equal and only one word should be written. They were informed that they could start by filling whichever space they wanted without any time restrictions since this application is not conducted to evaluate them and they are allowed to ask questions. The first 300 words of the six selected tales were transferred to the Word format in order to carry out the Çetinkaya-Uzun (Çetinkaya, 2010) cloze 
readability application. Afterwards, the following steps were performed to prepare the texts for implementation, which were specified in Bormuth's (1967) study and used by Çetinkaya (2010).

This process was performed until every fifth word was underlined and 50 words were reached, starting from the second sentence without deleting the words in the first sentence. After reaching 50 words, the remaining sentences were left untouched. While the texts were being formatted, "Times New Roman" was used as the font, the font style was set to "normal", and the font size was set to 12 . The text was written in double-space. Each underlined word was deleted, an underlined space was left in the 12 writing unit ranges, and an answer key was created with the words in which the space was placed. An explanation text was prepared to inform students about the study. It was stated in the explanatory text that the purpose of the application was not to test them, but to evaluate their knowledge. It was stated that there was no time limit when filling in the spaces in the text for the study, that the students should first read the text completely and then write the word they think would be suitable in each space. While evaluating the words that were filled out by the students, the words that were the same as the extracted words were accepted as correct. The number of words correctly filled in by the student in the given text was taken as the raw score and this score was multiplied by two to obtain the necessary result for the evaluation.

In addition to the steps mentioned above, a second evaluation process, in which synonyms were added instead of correct words (Ulusoy, 2009), was performed and it was aimed to determine the findings through two evaluations.

\subsection{Data analysis}

In the present study, data analysis was performed with the descriptive analysis technique. The formulas specified below were calculated by using the Microsoft Excel program after the number of sentences, words and syllables required in the implementation of the readability formulas were calculated. Papers collected in the cloze readability stage were examined by the researchers in three categories as true, false and use of synonym. When the words written were the same as the extracted word, it was stated as " correct cloze readability" and when both the word and the synonym corresponded to the extracted word, it was stated as "correct cloze readability and synonym" and the papers were evaluated. The evaluations were made according to the score averages, the score ranges, percentage, and percentage ranges. The data was described categorically, demonstrated with tables, and interpreted. Detailed information about the readability formulas used in the study is given below.

The Ateşman (1997) readability formula was created by taking two variables into consideration. These variables are sentence length and word length. The number of readability according to the formula and the reading levels corresponding to this number value range are as follows: Readability number $=$ $198.825-40.175 \times \mathrm{X} 1-2.610 \times \mathrm{X} 2(\mathrm{X} 1=$ average word length according to syllables, X2 = average sentence length according to words)

The relationship between readability and the number of readability is shown in Table 1 in order to evaluate the readability levels of fairy tale texts.

Table 1. Classification of Turkish texts according to the number of readability in the Ateşman Readability Formula

\begin{tabular}{ll}
\hline Readability & Number of Readability \\
\hline Very Easy & $90-100$ \\
\hline Easy & $70-89$ \\
\hline Medium & $50-69$ \\
\hline Difficult & $30-49$ \\
\hline Very Difficult & $1-29$ \\
\hline
\end{tabular}


Çetinkaya-Uzun (Çetinkaya, 2010) created a formula on the readability of Turkish texts. The readability numbers that emerge according to this formula and the reading levels corresponding to this number range are as follows: Readability Score $=118.823-25.987 \times$ OSU- $0.971 \times$ OTU (OSU $=$ Average word length, OTU $=$ Average sentence length)

In order to evaluate the readability levels of tales, the relationship between readability score, readability level, and education level was shown in Table 2.

Table 2. Classification of Turkish texts according to the number of readability in Çetinkaya-Uzun Readability Formula

\begin{tabular}{lll}
\hline Readability Score & Readability Level & Education Level \\
\hline $0-34$ & Challenging (Frustration) & $10^{\text {th }} 11^{\text {th }}$ and $12^{\text {th }}$ Grade \\
\hline $35-50$ & Educational Reading (Assisted) & $8^{\text {th }}$ and $9^{\text {th }}$ Grade \\
\hline $51+$ & Independent Reading & $5^{\text {th }} 6^{\text {th }}$ and $7^{\text {th }}$ Grade \\
\hline
\end{tabular}

The first 300 words of the six tales taken from two tale books were prepared as stated above. Table 3 shows the relationship between the cloze score and the readability level used in the evaluation of the tales given to the students.

Table 3. Readability level according to the cloze score

\begin{tabular}{ll}
\hline Cloze Score & Readability Level \\
\hline Less than 35\% & Challenging (Frustration) \\
\hline $35-50 \%$ & Educational Reading (Assisted) \\
\hline $51-60 \%$ & Independent Reading \\
\hline
\end{tabular}

\section{Results}

\subsection{Evaluation of the Tales according to the Readability Formulas}

Table 4 shows the readability levels of the six fairy tale texts selected from the two books according to the Ateşman readability formula.

Table 4. Evaluation according to the Ateşman Readability Formula

\begin{tabular}{|c|c|c|c|c|c|c|}
\hline \multirow{2}{*}{$\begin{array}{l}\text { Tale Book } \\
\text { and the } \\
\text { Selected } \\
\text { Tales }\end{array}$} & \multicolumn{3}{|c|}{ Az Gittik Uz Gittik } & \multicolumn{3}{|c|}{ Masal Masal İçinde } \\
\hline & $\begin{array}{l}\text { Dünya } \\
\text { Güzeli }\end{array}$ & $\begin{array}{l}\text { Tilki ile } \\
\text { Çimenci } \\
\text { Padişahının } \\
\text { Oğlu }\end{array}$ & Benli-Bahri & $\begin{array}{l}\text { Masal Masal } \\
\text { Íçinde }\end{array}$ & $\begin{array}{l}\text { Şapkacı'nın } \\
\text { Anlattıkları }\end{array}$ & $\begin{array}{l}\text { Köradam'ın } \\
\text { Anlattıkları }\end{array}$ \\
\hline \multirow{2}{*}{$\begin{array}{l}\text { Ateşman } \\
\text { readability } \\
\text { formula }\end{array}$} & 71.08-Easy & 85.54- Easy & 83.13- Easy & 72.28- Easy & 79.78- Easy & $\begin{array}{l}\text { 94.97-Very } \\
\text { Easy }\end{array}$ \\
\hline & \multicolumn{3}{|c|}{ 79.91- Easy } & \multicolumn{3}{|c|}{ 81.86- Easy } \\
\hline
\end{tabular}

When Table 4 is examined, it was observed that in the tale book Az Gittik Uz Gittik, the tale Dünya Güzeli had a readability score of 71.08 (easy) while this number was 85.54 (easy) for Tilki ile Çimenci Padişahının Oğlu and 72.28 (easy) for Benli-Bahri. In the tale book Masal Masal İçinde, the tale Masal Masal İçinde had a readability score of 72.28 (easy) while this number was 79.78 (easy) for Şapkacı'nın 
Anlattıkları and 94.97 (very easy) for Köradam'ın Anlattıkları. The readability conditions were determined to be easy for five tales and very easy for one tale. This finding indicates that the selected tales are easily readable according to Ateşman's readability formula.

The readability levels of the six fairy tales selected from the two books according to the ÇetinkayaUzun readability formula were demonstrated in Table 5.

Table 5. The evaluation performed according to the Çetinkaya-Uzun Readability Formula

\begin{tabular}{|c|c|c|c|c|c|c|}
\hline \multirow{2}{*}{$\begin{array}{l}\text { Tale Book } \\
\text { and the } \\
\text { Selected } \\
\text { Tales }\end{array}$} & \multicolumn{3}{|c|}{ Az Gittik Uz Gittik } & \multicolumn{3}{|c|}{ Masal Masal İçinde } \\
\hline & $\begin{array}{l}\text { Dünya } \\
\text { Güzeli }\end{array}$ & $\begin{array}{l}\text { Tilki ile } \\
\text { Çimenci } \\
\text { Padişahının } \\
\text { Oğlu }\end{array}$ & Benli-Bahri & $\begin{array}{l}\text { Masal Masal } \\
\text { Içinde }\end{array}$ & $\begin{array}{l}\text { Şapkacı'nın } \\
\text { Anlattıkları }\end{array}$ & $\begin{array}{l}\text { Köradam'ın } \\
\text { Anlattıkları }\end{array}$ \\
\hline \multirow{2}{*}{$\begin{array}{l}\text { Çetinkaya- } \\
\text { Uzun } \\
\text { readability } \\
\text { formula }\end{array}$} & $\begin{array}{l}\text { 43.36- } \\
\text { Educational } \\
\text { Reading }\end{array}$ & $\begin{array}{l}\text { 51.06- } \\
\text { Independent } \\
\text { Reading }\end{array}$ & $\begin{array}{l}51.16- \\
\text { Independent } \\
\text { Reading }\end{array}$ & $\begin{array}{l}\text { 44.14- } \\
\text { Educational } \\
\text { Reading }\end{array}$ & $\begin{array}{l}46.60- \\
\text { Educational } \\
\text { Reading }\end{array}$ & $\begin{array}{l}55.23- \\
\text { Independent } \\
\text { Reading }\end{array}$ \\
\hline & \multicolumn{3}{|c|}{ 48.52- Educational Reading } & \multicolumn{3}{|c|}{ 48.65- Educational Reading } \\
\hline
\end{tabular}

When Table 5 is examined, it was observed that in the tale book Az Gittik Uz Gittik, the tale Dünya Güzeli had a readability score of 43.56 (educational reading) while this number was 51.06 (independent reading) for Tilki ile Çimenci Padişahının Oğlu and 51.16 (independent reading) for Benli-Bahri. In the tale book Masal Masal Iç̧inde, the tale Masal Masal İçinde had a readability score of 44.14 (educational reading) while this number was 46.60 (educational reading) for Şapkacı'nın Anlattıkları and 55.23 (independent reading) for Köradam'ın Anlattıkları. The readability conditions were classified as educational reading for three tales and independent reading for three tales. It was observed that the average score of the three tales in the tale book Az Gittik Uz Gittik was 48.52 (educational reading), and the average score of the three tales in the tale book Masal Masal İçinde was 48.56 (educational reading). It was determined that the tales in both tale books were generally at the level of educational reading. This finding indicates that the selected tales are readable at the educational reading level according to the Çetinkaya-Uzun readability formula.

\subsection{Evaluation of Tales according to the Cloze Readability Application}

Table 6 shows the readability levels of the six fairy tales selected from the two books according to the cloze readability formula.

Table 6. The evaluation performed according to the cloze readability application

\begin{tabular}{|c|c|c|c|c|c|c|}
\hline \multirow{2}{*}{$\begin{array}{l}\text { Tale Book } \\
\text { and Selected } \\
\text { Tales }\end{array}$} & \multicolumn{3}{|c|}{ Az Gittik Uz Gittik } & \multicolumn{3}{|c|}{ Masal Masal İçinde } \\
\hline & $\begin{array}{l}\text { Dünya } \\
\text { Güzeli }\end{array}$ & $\begin{array}{l}\text { Tilki ile } \\
\text { Çimenci } \\
\text { Padişahının } \\
\text { Oğlu }\end{array}$ & Benli-Bahri & $\begin{array}{l}\text { Masal Masal } \\
\text { Içinde }\end{array}$ & $\begin{array}{l}\text { Şapkacı'nın } \\
\text { Anlattıkları }\end{array}$ & $\begin{array}{l}\text { Köradam'ın } \\
\text { Anlattıkları }\end{array}$ \\
\hline \multirow{2}{*}{$\begin{array}{l}\text { Cloze } \\
\text { readability } \\
\text { completely } \\
\text { correct }\end{array}$} & $\begin{array}{l}16.0(32 \% \\
\text { challenging) }\end{array}$ & $\begin{array}{l}16.7(33.4 \% \\
\text { challenging) }\end{array}$ & $\begin{array}{l}15.1(30.2 \% \\
\text { challenging) }\end{array}$ & $\begin{array}{l}16.8(33.6 \% \\
\text { challenging) }\end{array}$ & $\begin{array}{l}17.7(35.4 \% \\
\text { educational } \\
\text { reading) }\end{array}$ & $\begin{array}{l}21.6(43.2 \% \\
\text { educational } \\
\text { reading) }\end{array}$ \\
\hline & \multicolumn{3}{|c|}{15.9 (31.8\% challenging) } & \multicolumn{3}{|c|}{18.7 (37.4\% challenging) } \\
\hline \multirow{2}{*}{$\begin{array}{l}\text { Cloze } \\
\text { readability } \\
\text { completely } \\
\text { correct and } \\
\text { synonym }\end{array}$} & $\begin{array}{l}29.7(59.4 \% \\
\text { independent } \\
\text { reading) }\end{array}$ & $\begin{array}{l}24.5(49 \% \\
\text { educational } \\
\text { reading })\end{array}$ & $\begin{array}{l}26.5(53 \% \\
\text { independent } \\
\text { reading) }\end{array}$ & $\begin{array}{l}25.9(51.8 \% \\
\text { independent } \\
\text { reading })\end{array}$ & $\begin{array}{l}27.3(54.6 \% \\
\text { independent } \\
\text { reading) }\end{array}$ & $\begin{array}{l}32.1(64.2 \% \\
\text { independent } \\
\text { reading })\end{array}$ \\
\hline & \multicolumn{3}{|c|}{$26.9(53.8 \%$ independent reading $)$} & \multicolumn{3}{|c|}{$28.4(56.8 \%$ independent reading) } \\
\hline
\end{tabular}


When Table 6 is examined, it was observed that in the tale book Az Gittik Uz Gittik, the tale Dünya Güzeli had a correct cloze readability score of 16.0 (32\% challenging) while this number was 16.7 (33.4\% challenging) for Tilki ile Çimenci Padişahının O $\breve{g} l u$ and 15.1 (30.2\% challenging) for BenliBahri. In the tale book Masal Masal Iç̧inde, the readability score of the tale Masal Masal İçinde was 16.8 (33.6\% challenging) while this number was 17.7 (35.4\% educational reading) for Şapkacı'nın Anlattıları and 21.6 (43.2\% educational reading) for Köradam'in Anlattıklart. It was determined that the book $\mathrm{Az}$ Gittik $\mathrm{Uz}$ Gittik had an average correct cloze readability score of 15.9 (31.8\% challenging) and the average score of Masal Masal İçinde was 18.7 (43.2\% challenging). It was also determined that the readability conditions of the tales included in Az Gittik $\mathrm{Uz}$ Gittik were challenging (difficult) while one of the tales included in Masal Masal İçinde was classified as challenging (difficult) and two tales were at the level of educational reading. This finding indicates that the tales in the tale book $\mathrm{Az}$ Gittik Uz Gittik have better readability for the students compared to the tales in the book Masal Masal Içinde according to the cloze readability application.

When the synonymous words were accepted as correct in the cloze readability application, it was observed that in the tale book $A z$ Gittik $U z$ Gittik, the correct cloze readability and synonym score of the tale Dünya Güzeli was 29.7 (59.4\% independent reading) while this number was 24.5 (49\% educational reading) for Tilki ile Çimenci Padişahının Oğlu and 26.5 (53\% independent reading) for Benli-Bahri. In the tale book Masal Masal İçinde, the tale Masal Masal İçinde had a correct cloze readability and synonym score of Masal Masal Içinde tale was 25.9 (51.8\% independent reading) while this number was 27.3 (54.6\% independent reading) for Şapkacı'nın Anlattıkları and 32.1 (64.2\% independent reading) for Köradam 'ın Anlattıklarl. It was determined that the tale book Az Gittik Uz Gittik had an average correct cloze readability and synonym score of 29.9 (53.8\% independent reading) while the book Masal Masal İçinde had an average score of 28.4 (56.8\% independent reading). It was also determined that the readability conditions of the tales included in the books Az Gittik Uz Gittik and Masal Masal İçinde were at the level of independent reading. This finding indicates that the tales in the tale book Az Gittik Uz Gittik have better readability for the students compared to the tales in the book Masal Masal İçinde according to the correct cloze readability and synonym application.

In the correct cloze readability application, the average score of the three tales selected from the book Masal Masal İçinde was higher than the three fairy tales selected from the book Az Gittik Uz Gittik. In the correct cloze readability and synonym application, the average score of the three fairy tales selected from the tale book $A z$ Gittik $U z$ Gittik was close to the average of the three fairy tales selected from the tale book Masal Masal İçinde. This result indicates that the students were unsuccessful in writing the same words in the book Az Gittik Uz Gittik, which was written earlier, but they were successful in using the synonyms included in the book since the tales in the book Az Gittik Uz Gittik were written by Pertev Naili Boratav in a matter that is true to the original. The book Masal Masal İçinde, on the other hand, consists of tales that were written with the author's own style, influenced by the tales that he had heard from his mother in a more recent period. In the cloze readability application, students were more successful in writing the words correctly in the Masal Masal Içinde tale book, which was written more recently and based on the author's own style. This result indicates that the language used at the time of writing may affect the readability of the tales.

\subsection{Evaluation of Cloze Readability Application in terms of the Variables}

Table 7 shows the evaluation of the data obtained with the Çetinkaya-Uzun cloze readability application in terms of the gender variable. 
Table 7. The evaluation performed in cloze readability application according to the gender variable

\begin{tabular}{lll}
\hline Categories & Female (73) & Male (17) \\
\hline Az Gittik Uz Gittik / completely correct & 16.7 & 12.6 \\
Masal Masal İçinde / completely correct & 19.5 & 15.1 \\
\hline Az Gittik Uz Gittik / completely correct and & 27.7 & 23.6 \\
$\begin{array}{l}\text { synonym } \\
\text { Masal Masal İçinde / completely correct and }\end{array}$ & 29.5 & 23.8 \\
synonym & & \\
\hline
\end{tabular}

When Table 7 is examined, it was observed that in the distribution of score averages obtained from the correct cloze readability application according to the gender variable, the female students had a score average of 16.7 from the three tales included in the book Az Gittik $U z$ Gittik while the male students had a score average of 12.6. The female students had a score average of 19.5 from the three tales included in the book Masal Masal İçinde while the male students had a score average of 15.1. In the correct cloze readability application, the score average of female students was higher than the male students from the tales in both books and it was determined that the score averages of both male and female students were higher in the tales from the book Masal Masal İçinde compared to the tales included in the book $\mathrm{Az}$ Gittik $U z$ Gittik. This result indicates that female students understood the tales they read more accurately than male students, and the tales in the book Masal Masal Iç̧inde were better understood by the students compared to the fairy tales in the tale book Az Gittik Uz Gittik.

When Table 7 is examined, it is observed that in the distribution of the score averages obtained from the correct cloze readability and synonym application according to the gender variable, the female students had a score average of 27.7 from the three tales included in the book Az Gittik Uz Gittik while the male students had a score average of 23.6. The female students had a score average of 29.5 from the three tales included in the tale book Masal Masal Içinde while the male students had a score average of 23.8. In the correct cloze readability and synonym application, the score average of the female students was higher than the male students from the tales in both books and it was determined that the score averages of both the male and female students were higher in the tales from the book Masal Masal Içinde compared to the tales included in the book Az Gittik $U z$ Gittik. This result indicates that female students understood the tales they read more accurately than male students, and the tales in the book Masal Masal İçinde were better understood by the students compared to the fairy tales in the tale book Az Gittik Uz Gittik.

The evaluation of the data obtained with the Çetinkaya-Uzun cloze readability application in terms of the grade variable was given in Table 7.

Table 8. The evaluation performed in cloze readability application according to the grade variable

\begin{tabular}{lllll}
\hline Categories & $\begin{array}{l}\mathbf{5}^{\text {th }} \text { Grade } \\
(\mathbf{2 5})\end{array}$ & $\begin{array}{l}\mathbf{6}^{\text {th }} \text { Grade } \\
(\mathbf{2 1})\end{array}$ & $\begin{array}{l}\mathbf{7}^{\text {th }} \text { Grade } \\
(\mathbf{2 2})\end{array}$ & $\begin{array}{l}\mathbf{8}^{\text {th }} \text { Grade } \\
(\mathbf{2 2})\end{array}$ \\
\hline Az Gittik Uz Gittik / completely correct & 12.3 & 14.9 & 17.0 & 19.9 \\
Masal Masal İcinde / completely correct & 15.2 & 17.4 & 20.4 & 22.2 \\
\hline $\begin{array}{l}\text { Az Gittik Uz Gittik / completely correct and } \\
\text { synonym }\end{array}$ & 21.1 & 27.0 & 30.7 & 29.6 \\
$\begin{array}{l}\text { Masal Masal İçinde / completely correct and } \\
\text { synonym }\end{array}$ & 22.2 & 27.6 & 32.9 & 31.7 \\
\hline
\end{tabular}

When Table 7 is examined, it is observed that in the distribution of score averages obtained from the correct cloze readability application according to the grade variable, the 5th-grade students had a score average of 12.3 from the three tales included in the tale book $A z$ Gittik $U z$ Gittik while this number was 
14.9 for 6 th-grade students, 17.0 for 7 th-grade students, and 19.9 for 8 th-grade students. The 5 th-grade students had a score average of 15.2 from the three tales included in Masal Masal İçinde while this number was 17.4 for 6 th-grade students, 20.4 for 7 th-grade students, and 22.2 for 8 th-grade students. It was determined that in the cloze readability application, the average scores obtained from both fairy tale books increased in parallel with grade level. Additionally, the average scores obtained from the three tales included in the tale book Masal Masal Içinde were higher in each grade compared to the three tales in the tale book $\mathrm{Az}$ Gittik $\mathrm{Uz}$ Gittik. This result indicates that the tales were better understood as the grade level increased in the correct cloze readability application and that the tale book Masal Masal İçinde had better readability than the book Az Gittik Uz Gittik.

When Table 7 is examined, it is observed that in the distribution of the score averages obtained from the correct cloze readability and synonym application according to the grade variable, the 5th-grade students had a score average of 21.1 from the three tales included in the tale book Az Gittik Uz Gittik while this number was 27.0 for 6th-grade students, 30.7 for 7 th-grade students, and 29.6 for 8 th-grade students. The 5th-grade students had a score average of 22.2 from the three tales included in Masal Masal İçinde while this number was 27.6 for 6th-grade students, 32.9 for 7 th-grade students, and 31.7 for 8th-grade students. It was determined that the readability of tales increased in the 5th, 6th, and 7th grades in the correct cloze readability and synonym application, however, the score averages of the 8thgrade students were lower than the 7th-grade students. Additionally, the average scores obtained from the three tales included in the tale book Masal Masal Içinde were higher than the three tales included in the tale book $\mathrm{Az}$ Gittik $\mathrm{Uz}$ Gittik. This result indicates that the readability of the tales increased in the 5th, 6th, and 7th grades in the correct cloze readability and synonym application, however, there was a decrease in the 8th-grade students and the tale book Masal Masal Iç̧inde was more readable than the tale book Az Gittik Uz Gittik.

\section{Discussion}

In the study conducted by Zorbaz (2007) on the readability levels of tales included in course books, it was determined that the readability levels of tales used in primary school level were generally easy. This result is similar to the results of the present study. No readability studies conducted in accordance with the Ateşman formula were found. There are readability studies in the literature directed at course books rather than tales (Akkurt, 2011; Bağc1 \& Ünal, 2013; Baş \& İnan-Yıldız, 2015; Çakmak \& Çi1, 2014; Çiftçi, Çeçen \& Melanlıŏlu, 2007; Demir \& Çeçen, 2013; Erdem, 2011; Solmaz, 2009; UluKalın, 2017). There were also readability studies directed at narrative texts rather than tales in children's literature (Çeçen \& Aydemir, 2011; Çinpolat, 2019; Kayabaşı, Yılmaz \& Doyumğaç, 2016; Rada, 2016; Teke, 2016; Temizyürek, 2010).

Çetinkaya-Uzun readability formula was also used in this study. No studies on tales that were conducted with the Çetinkaya-Uzun readability formula were found in the literature. There are readability studies in the literature directed at course books rather than tales (Bağc1 \& Ünal, 2013; Bozlak, 2018; Okur \& Ar1, 2013). There are also readability studies directed at narrative texts rather than tales in children's literature (Çinpolat, 2019; Kayabaşı, Yılmaz \& Doyumğaç, 2016).

Also, cloze test method was applied in this study. No studies on tales that were conducted with the cloze readability application were found in the literature. There are readability studies directed at course books rather than tales. There are studies on the cloze readability application directed at texts in course books (Çinpolat, 2019; Karatay, Bolat \& Güngör, 2013; Çetinkaya, 2010). 


\section{Conclusions}

Within the scope of the research, a total of six fairy tale texts in the books Az Gittik Uz Gittik and Masal Masal İçinde were examined according to two readability formulas and the cloze readability applications of the same fairy tales were applied to middle-school students. The results obtained were presented below.

According to the Ateşman readability formula, it was concluded that the tales Dünya Güzeli, Tilki ile Çimenci Padişahının Oğlu, and Benli-Bahri included in the book Az Gittik Uz Gittik had a readability level classified as easy, the tales Masal Masal İçinde and Şapkacı'nın Anlattıkları included in Masal Masal İçinde had a readability level classified as easy, and Köradam'ın Anlattıkları had a readability level classified as very easy. Five tales had readability conditions classified as easy, and one tale had a readability condition of very easy. This result indicates that the selected tales are easily readable according to Ateşman's readability formula.

According to the Çetinkaya-Uzun readability formula, it was concluded that the readability level of the tale Dünya Güzeli included in Az Gittik Uz Gittik was classified as educational reading while the tales Tilki ile Çimenci Padişahının Oğlu and Benli-Bahri were classified as independent reading. The tales Masal Masal İçinde and Şapkacı'nın Anlattıkları included in Masal Masal İçinde were classified as educational reading, and the tale Köradam 'in Anlattıkları was classified as independent reading. The readability condition of the three tales in Az Gittik Uz Gittik was classified as educational reading and the readability condition of the three tales in Masal Masal İçinde was determined as independent reading. It can be stated that the tales in both books were generally at the level of educational reading. This result indicates that the selected tales are readable at the educational reading level according to the Çetinkaya-Uzun readability formula.

According to the cloze readability application, it was concluded that the tales Dünya Güzeli, Tilki ile Çimenci Padişahının Oğlu and Benli-Bahri included in the book Az Gittik Uz Gittik had a precise readability condition classified as challenging (difficult), the tale Masal Masal $\dot{I}_{c}$ inde included in the book Masal Masal İçinde was classified as challenging (difficult) and the tales Sapkacı'nın Anlattıkları and Köradam'in Anlattıklarl were at the level of educational reading. It was determined that the tales included in the book Az Gittik $\mathrm{Uz}$ Gittik were challenging (difficult) while one of the tales in Masal Masal Içinde was challenging (difficulty) and two of them were at the level of educational reading. This finding indicates that the tales included in the book Masal Masal İçinde had better readability for the students compared to the tales in $A z$ Gittik $U z$ Gittik according to the cloze readability application.

When the synonymous words were accepted as correct along with the completely correct words in the cloze readability application, it was observed that in the tale book Az Gittik Uz Gittik, the correct cloze readability and synonym condition of the tales Dünya Güzeli and Benli-Bahri were classified as independent reading and the tale Tilki ile Çimenci Padişahının Oğlu was classified as educational reading. In the tale book Masal Masal İçinde, the tales Masal Masal İçinde and Şapkacı'nın Anlattıkları were classified as independent reading. It was determined that the tales included in Az Gittik Uz Gittik and Masal Masal Içinde were at the level of independent reading. When the synonyms are added to the cloze readability application, this result indicates that the tales included in Az Gittik Uz Gittik and Masal Masal İcinde are readable for the students.

In the cloze readability application, the average score of the three tales selected from the book Masal Masal İçinde was higher than the average score of the three tales selected from the book Az Gittik $U z$ Gittik. In the correct cloze readability and synonym application, the average score of the three tales selected from the tale book Az Gittik Uz Gittik was found to be close to the average of the three fairy tales selected from the book Masal Masal İcinde. This result indicates that the students were unsuccessful in writing the same words as in the book Az Gittik $U z$ Gittik, which was written earlier, but 
they were successful in using the synonyms included as the tales in the book Az Gittik Uz Gittik book were written by Pertev Naili Boratav in a manner that is true to the original. The book Masal Masal Içinde, on the other hand, consists of tales that were written with the author's own style, influenced by the tales that he had heard from his mother in a more recent period. In the cloze readability application, students were more successful in writing the words correctly in the Masal Masal Içinde tale book, which was written more recently and based on the author's own style. This result indicates that the language used at the time of writing may affect the readability of the tales.

In the correct cloze readability and synonym application, the score average of the female students was higher than the male students from the tales in both books and it was determined that the score averages of both the male and female students were higher in the tales from the book Masal Masal Íçinde compared to the tales included in the book Az Gittik Uz Gittik. This result indicates that female students understood the tales they read more accurately than male students, and the tales in the book Masal Masal İçinde were better understood by the students compared to the fairy tales in the tale book $A z$ Gittik $U z$ Gittik. It was determined that in the cloze readability application, the average scores obtained from both fairy tale books increased in parallel with grade level. Additionally, the average scores obtained from the three tales included in the tale book Masal Masal Iç̧inde were higher in each grade compared to the three tales in the tale book Az Gittik $U z$ Gittik. This result indicates that the tales were better understood as the grade level increased in the correct cloze readability application and that the tale book Masal Masal İçinde had better readability than the book Az Gittik Uz Gittik. In the correct cloze readability and synonym application, the average scores from both tale books increased from the 5th grade to the 7th grade, however, the average scores of the 8th-grade students higher were lower compared to the 7th-grade students. Furthermore, the average scores from the three fairy tales included in the tale book Masal Masal İçinde were higher in each grade level compared to the three fairy tales in the tale book Az Gittik Uz Gittik. This result indicates that the readability of the tales increased throughout the 5th, 6th, and 7th grade levels in the correct cloze reading and synonym application although there was a decrease in the 8th-grade level, and the tale book Masal Masal İçinde was more readable than the tale book $A z$ Gittik $U z$ Gittik.

Overall, it can be stated that the books titled Az Gittik Uz Gittik and Masal Masal İçinde are easily readable according to the readability formulas. According to the data obtained from middle school students, it can be stated that the book Az Gittik Uz Gittik is more challenging than Masal Masal Iç̧inde. In this case, it can be said that the language in which the tales were written, and the characteristics of the period are decisive in students' comprehension of the tale texts as the publishing dates of the tale books are different from each other. It can be concluded that the fairy tale book Masal Masal Içinde, which was published more recently, is easier to comprehend by the students.

Following suggestions were developed in accordance with the results of the study:

1. Choosing suitable books based on the readability status of the tales that would be taught to the students and included in the textbooks,

2. Using contemporary Turkish in modern fairy tales to be written,

3. Old fairy tale books can be adapted based on Modern Turkish for better comprehension.

\section{Ethics Committee Approval}

The author confirms that ethics committee approval was obtained from Ordu University Social and Humanitary Sciences Researches Ethics Committee (Approval Date and Number: 29/04/2020, 2020$34)$. 


\section{References}

Akçaalan, H. (2015). Tales in the point of functional theory and the evaluation of the state of tales in today's Kütahya (Unpublished Master's Thesis). Kütahya Dumlupınar University, Kütahya, Turkey.

Ateşman, E. (1997). Türkçede okunabilirliğin ölçülmesi. Ankara Üniversitesi TÖMER Dil Dergisi, 58, 171-174.

Bağc1, H., \& Ünal, Y. (2013). Readability of texts in 8th grade Turkish textbooks. Journal of Mother Tongue Education, 1(3), 12-28.

Baş, B., \& İnan-Yıldız, F. (2015). Review of texts in 2nd class Turkish textbook in terms of readability. Mersin University Journal of the Faculty of Education, 11(1), 52-61.

Bilkan, A. F. (2009). Masal estetiği. İstanbul: Timaş Yayınları.

Boratav, P. N. (2008). Az gittik uz gittik (4 ${ }^{\text {th }}$ ed.). İstanbul: İmge Kitabevi.

Bormuth, J. R. (1967). The implications of the use of cloze procedure in the evaluation of instructional programs. Occasional Report No. 3. Center for the Study of Evaluation of Instructional Programs, University of California, Los Angeles, USA.

Bozlak, Ü. G. (2018). The readability levels of stroytelling texts in the fifth grade Turkish text books with the formula developed by uzun-çetinkaya at 2016-2017 and 2017-2018 education and training period. Akra Kültür Sanat ve Edebiyat Dergisi, 6(14), 209-234.

Ceran, D. (2015). The Evaluation of readability levels of the books being in category "Turkish literature" of the list of a hundred fundamental works and the opinions of 7th grade students on these books. Journal of Language and Literature Education, 14, 23-51.

Christensen, L. B., Johnson, R. B., \& Turner, L. A. (2015). Araştırma yöntemleri desen ve analiz (2 $2^{\text {nd }}$ ed.) (A. Aypay, Trans.). Ankara: Anı Yayıncılık.

Creswell, J. W. (2013). Research design: qualitative, quantitative, and mixed methods approaches. New York: Sage.

Çakmak, G., \& Çil, E. (2014). Evaluation of 4th grade science and technology course book with readability formulas: The case of exploring and knowing the world of living creatures.Turkish Journal of Educational Studies, 1(3), 1-26.

Çeçen. M. A., \& Aydemir, F. (2011). A study on pre-school story books in point of readability. Mustafa Kemal University Journal of Social Sciences Institute, 8(6), 185-194.

Çetinkaya, G. (2010). Identifying and classifying the readability levels of the Turkish texts (Unpublished Doctorate Thesis). Ankara University, Ankara, Turkey.

Çiftçi, Ö, Çeçen, M. A., \& Melanlıŏlu, D. (2007). An evaluation of the texts of sixth grade Turkish course books in terms of readability. Electronic Journal of Social Sciences,6(22), 206-219.

Çinpolat, E. (2019). Miyase Sertbarut'un kitaplarının okunabilirlik düzeyleri (Unpublished Master's Thesis). Ordu University, Ordu, Turkey.

Demir, M., \& Çeçen, M. A. (2013). An evaluation on texts of Ist-Vth classes Turkish course books in term of readability. Journal of National Education, 197, 80-94.

Dilidüzgün, S. (2003). Çağdaş çocuk yazını. İstanbul: Morpa Kültür.

Erdem, C. (2011). An evaluation on the texts' word-sentence lengt and readability levels in language and speech books (Unpublished Master's Thesis). Gazi University, Ankara, Turkey. 
Güneş, F. (2000). Çocuk kitaplarının okunabilirlik ölçütleri açısından incelenmesi. I. Ulusal Çocuk Kitapları Sempozyumu. Ankara: Ankara Üniversitesi TÖMER Dil Öğretim Merkezi Yayınları.

Güney, E. C. (1974). Folklor ve eğitim. Ankara: Milli Eğitim Basımevi.

Ilıcak, N. G. (2014). Determination and examination of elements in folk culture and folk literature after 1980 in Turkish novel (Unpublished Doctorate Thesis). İstanbul University, İstanbul, Turkey.

Karasar, N. (2012). Bilimsel araştırma yöntemleri. Ankara: Nobel Yayıncılık.

Karatay, H. (2007). The function and importance of tale in language acquisition cultural worth instruction process. The Journal of Turkish Educational Sciences, 5(3), 463- 477.

Karatay, H., Bolat, K. K., \& Güngör, H. (2013). The readability and understandability of the texts in the course books of Turkish language courses. The Journal Academic Social Science Studies, 6(6), 603623. doi: http://dx.doi.org/10.9761/JASSS1770

Kayabaşı, B., Yılmaz, M., \& Doyumğaç, İ. (2016). Examination of Mustafa Ruhi Şirin's stories in terms of readability. Adlyaman University Journal of Educational Sciences, 6(2), 323-343.

Okur, A., \& Arı, G. (2013). Readability of texts Turkish textbooks in grades 6, 7, 8. Elementary Education Online, 12(1), 202-226.

Rada, M. (2016). An evalutation of Uçurtma Mevsimi story book of Kaan Murat Yanık, in terms of readability (Unpublished Master's Thesis). Sakarya University, Sakarya, Turkey.

Sever, S. (2003). Çocuk ve edebiyat. Ankara: Kök Yayıncılık.

Solmaz, E. (2009). The effects of sentence lenght, word lenght and vocabulary items on readability of Turkish text in 4th and 5th grade students (Unpublished Master's Thesis). Gazi University, Ankara, Turkey.

Şirin, M. R. (2000). Çocuk edebiyatı. İstanbul: Çocuk Vakfı Yayınları.

Tansel, O. (2009). Al'lı ile firfirı (Vol. 1). Ankara: Elips Kitap.

Teke, S. (2016). An evaluation of stories of Hasan Kallimci, author of children's literature, in terms of readiblity (Unpublished Master's Thesis). Sakarya University, Sakarya, Turkey.

Temizyürek, F. (2010). The investigation of the word and sentence length and the readability of the books which are selected in Turkey for the purpose of reading literacy. Journal of Turkology Research, 27, 645-654.

Tosunoğlu, M., \& Özlük, Y. Ö. (2011). The readability and the evaluation of proses in Turkish course book for the first year students in primary education in terms of readability. Journal of National Education, 189, 219-230.

Ulu-Kalın, Ö. (2017). Analysis of 7th grade social studies course book according to different readability formulas. International Online Journal of Educational Sciences, 9(4), 976-987. doi: https://doi.org/10.15345/iojes.2017.04.007

Ulusoy, M. (2009). Using cloze test to measure students' reading levels and readability of texts. The Journal of Turkish Educational Sciences, 7(1), 105-126.

Ümit, A. (2017). Masal masal içinde (52 ed. .). İstanbul: Everest Yayınları.

Yalçın, A., \& Aytaş, G. (2002). Çocuk edebiyatı. Ankara: Akçağ Yayınları.

Yavuz, M. H. (2002). Masallar ve eğitimsel işlevleri. Ankara: Kültür Bakanlığı Yayınları. 
Zorbaz, K. Z. (2007). An evaluation on the word-sentence lengths and readability levels of tales in Turkish textbooks. Journal of Theory and Practice in Education, 3(1), 87-101.

\section{Türk masallarının okunabilirliği}

\section{Öz}

Araştırmanın amacı, Türk masallarının okunabilirlik düzeylerini ve ortaokul öğrencileri için anlaşılırlığını belirlemektir. Araştırma, tarama modeliyle yürütülmüştür. Çalışma materyalini Az Gittik Uz Gittik ve Masal Masal İçinde kitabından seçilen üçer masal ve çalışma grubunu 2018-2019 eğitim-öğretim yılı bahar yarıyılında, bir ilin merkez ilçesinde bir ortaokulda öğrenim gören 90 öğrenci oluşturmaktadır. Veri toplama araçlarını; Ateşman okunabilirlik formülü, Çetinkaya-Uzun okunabilirlik formülü ve çıkartmalı okunabilirlik uygulaması oluşturmaktadır. Veriler iki aşamada toplanmıştır. Birinci aşamada okunabilirlik formüllerinin uygulanması amacıyla masalların ilk yüz kelimelik kısımları hesaplama için alınarak okunabilirlik durumları ortaya çıkarılmışıı. İkinci aşamada çıkartmalı okunabilirlik uygulaması, çalışma grubuna haftada iki metin uygulaması yapılarak üç haftada tamamlanmıştır. Veriler, betimsel analiz tekniği ile çözümlenmiştir. Masalların Ateşman okunabilirlik formülüne göre okunabilirlik durumlarının kolay düzey, Çetinkaya-Uzun okunabilirlik formülüne göre eğitsel okuma düzeyinde; çıkartmalı okunabilirlik uygulamasına göre Az Gittik Uz Gittik masal kitabının öğrenciler tarafından okunabilirlik durumlarının engelli düzey (zor), Masal Masal İçinde masal kitabında yer alan masalların ise eğitsel okuma düzeyinde olduğu belirlenmiştir.

Anahtar sözcükler: okuma alışkanlığı; Türk masalları; okunabilirlik; çıkartmalı okunabilirlik

\section{AUTHOR BIODATA}

Assoc. Prof. Dr. Keziban Tekşan, Ordu University, Faculty of Education, Department of Turkish and Social Sciences Education, Turkish Language Teaching. ORCID: 0000-0002-5768-0022

Assist. Prof. Dr. Üzeyir Süğümlü, Ordu University, Faculty of Education, Department of Turkish and Social Sciences Education, Turkish Language Teaching. ORCID: 0000-0003-2135-5399

Enes Çinpolat, PhD student in Turkish Education at Tokat Gaziosmanpaşa University. ORDCID: 0000-0002$3411-4300$ 